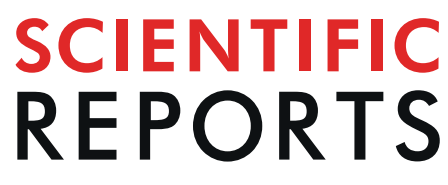

natureresearch

\title{
OPEN
}

Published online: 03 March 2020

\section{Author Correction: Analysis of sequencing strategies and tools for taxonomic annotation: Defining standards for progressive metagenomics}

\author{
Alejandra Escobar-Zepeda (1D, Elizabeth Ernestina Godoy-Lozano $(\mathbb{D}$, Luciana Raggi,

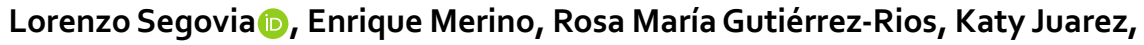 \\ Alexei F. Licea-Navarro $\mathbb{D}$, Liliana Pardo-Lopez \& Alejandro Sanchez-Flores
}

Correction to: Scientific Reports https://doi.org/10.1038/s41598-018-30515-5, published online 13 August 2018

The website on which the data underlying the study reported in Reference 17 was stored is no longer maintained. As such, in the Materials and Methods section, under subheading 'In silico datasets for WMS and 16S rRNA profiling,

"Sequences can be found at http://www.ucbioinformatics.org/metabenchmark.html."

should read:

"Sequences can be found at https://zenodo.org/record/3662895\#.XkMnZnUzbRI."

(c) (1) Open Access This article is licensed under a Creative Commons Attribution 4.0 International License, which permits use, sharing, adaptation, distribution and reproduction in any medium or format, as long as you give appropriate credit to the original author(s) and the source, provide a link to the Creative Commons license, and indicate if changes were made. The images or other third party material in this article are included in the article's Creative Commons license, unless indicated otherwise in a credit line to the material. If material is not included in the article's Creative Commons license and your intended use is not permitted by statutory regulation or exceeds the permitted use, you will need to obtain permission directly from the copyright holder. To view a copy of this license, visit http://creativecommons.org/licenses/by/4.0/.

(C) The Author(s) 2020 